WellBeing International

WBI Studies Repository

2012

\title{
Characterisation of Chemosensory Trigeminal Receptors in the Rainbow Trout, Oncorhynchus mykiss: Responses to Chemical Irritants and Carbon Dioxide
}

\author{
Jessica J. Mettam \\ University of Liverpool \\ Catherine R. McCrohan \\ University of Manchester \\ Lynne U. Sneddon \\ University of Liverpool
}

Follow this and additional works at: https://www.wellbeingintlstudiesrepository.org/acwp_vsm

Part of the Animal Studies Commons, Other Animal Sciences Commons, and the Veterinary

Physiology Commons

\section{Recommended Citation}

Mettam, J. J., McCrohan, C. R., \& Sneddon, L. U. (2012). Characterisation of chemosensory trigeminal receptors in the rainbow trout, Oncorhynchus mykiss: responses to chemical irritants and carbon dioxide. The Journal of experimental biology, 215(4), 685-693.

This material is brought to you for free and open access by WellBeing International. It has been accepted for inclusion by an authorized administrator of the WBI Studies Repository. For more information, please contact wbisr-info@wellbeingintl.org.

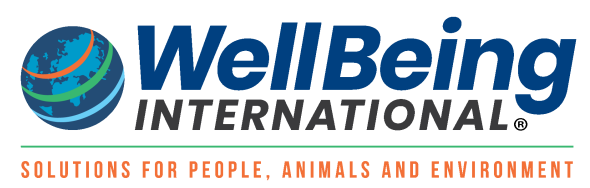




\title{
RESEARCH ARTICLE
}

\section{Characterisation of chemosensory trigeminal receptors in the rainbow trout, Oncorhynchus mykiss: responses to chemical irritants and carbon dioxide}

\author{
Jessica J. Mettam ${ }^{1}$, Catherine R. McCrohan ${ }^{2}$ and Lynne U. Sneddon ${ }^{1,3, *}$ \\ ${ }^{1}$ University of Liverpool, School of Biological Sciences, Liverpool L69 7ZB, UK, ${ }^{2}$ University of Manchester, Faculty of Life Sciences, \\ AV Hill Building, Manchester M13 9PT, UK and ${ }^{3}$ University of Chester, Biological Sciences, Chester CH1 4BJ, UK \\ *Author for correspondence (Isneddon@liverpool.ac.uk)
}

Accepted 22 October 2011

\begin{abstract}
SUMMARY
Trigeminally innervated, mechanically sensitive chemoreceptors (M) were previously identified in rainbow trout, Oncorhynchus mykiss, but it is not known whether these receptors are responsive only to noxious, chemical irritants or have a general chemosensory function. This study aimed to characterise the stimulus-response properties of these receptors in comparison with polymodal nociceptors $(P)$. Both $P$ and $M$ gave similar response profiles to acetic acid concentrations. The electrophysiological properties were similar between the two different afferent types. To determine whether the receptors have a nociceptive function, a range of chemical stimulants was applied to these receptors, including non-noxious stimuli such as ammonium chloride, bile, sodium bicarbonate and alarm pheromone, and potentially noxious chemical irritants such as acetic acid, carbon dioxide, low pH, citric acid, citric acid phosphate buffer and sodium chloride. Only irritant stimuli evoked a response, confirming their nociceptive function. All receptor afferents tested responded to carbon dioxide $\left(\mathrm{CO}_{2}\right)$ in the form of mineral water or soda water. The majority responded to $1 \%$ acetic acid, $2 \%$ citric acid, citric acid phosphate buffer ( $\mathrm{pH}_{3}$ ) and $5.0 \mathrm{moll}^{-1} \mathrm{NaCl}$ $\mathrm{CO}_{2}$ receptors have been characterised in the orobranchial cavity and gill arches in fish; however, this is the first time that external $\mathrm{CO}_{2}$ receptors have been identified on the head of a fish. Because the fish skin is in constant contact with the aqueous environment, contaminants with a low pH or hypercapnia may stimulate the nociceptive system in fish.
\end{abstract}

Key words: chemoreception, $\mathrm{CO}_{2}$, nociception, salmonid.

\section{INTRODUCTION}

Studies have identified cutaneous nociceptors in a teleost fish, the rainbow trout (Oncorhynchus mykiss Walbaum 1792), innervated by the trigeminal nerve (Sneddon, 2002; Sneddon, 2003; Sneddon et al., 2003). Sneddon (Sneddon, 2002) anatomically identified a range of afferent fibre types within the trigeminal nerve, including $\mathrm{A} \delta$ and $\mathrm{C}$ fibres, which transmit nociceptive information in mammals (Willis, 1988). Five different receptor types were characterised on the head of trout: polymodal nociceptors, mechanothermal nociceptors, mechanochemical receptors, and fast-adapting and slowly adapting mechanical receptors (Sneddon, 2003). The trout nociceptors demonstrated many similarities to the physiological properties of mammalian nociceptors (Sneddon, 2002; Sneddon, 2003; Sneddon et al., 2003). However, although the mechanochemical receptors responded in a slowly adapting fashion to mechanical stimulation and were stimulated by application of a noxious chemical, it was not possible to conclude that they had a solely nociceptive function as they could simply have been mechanically sensitive chemoreceptors (Sneddon, 2003).

A number of studies have investigated the chemosensitivity of epidermal receptors in a range of taxa including amphibians, birds and mammals (Carstens et al., 1998; Kumazawa and Mizumura, 1980; McKeegan, 2004). Chemosensory nociceptors located on the skin (Davis et al., 1993) and the nasal (McKeegan et al., 2002; Peppel and Anton, 1993), oral (Toda et al., 1997) and ocular (Carstens et al., 1998) mucosas are stimulated either by exposure to gaseous stimulants or by direct application of liquids (Hamamoto and
Simone, 2003; McKeegan et al., 2002; Peppel and Anton, 1993). These studies demonstrated that chemosensitive nociceptors may respond to multiple irritant compounds. However, some receptors only respond to one type of chemical whereas others respond to two or more (Carstens et al., 1998; McKeegan, 2004). Additionally, these receptors respond to chemicals in a concentration-related manner (Carstens et al., 1998; Peppel and Anton, 1993) and can display receptor desensitisation (Sekizawa and Tsubone, 1994) or sensitisation (Sekizawa et al., 1998). Further work suggests that both mechanochemical and polymodal nociceptors exhibit these responses (Hamamoto and Simone, 2003; Mason et al., 1996), although many studies do not distinguish between receptor types.

The olfactory and gustatory systems of fish have been well studied (Hara, 1994; Folgueira et al., 2003), but there is less information available on the sensitivity and specificity of other chemosensory receptors, particularly in relation to any nociceptive function. The only agent that has been investigated to any degree with respect to nociception is acetic acid, although bee venom has been shown to have an adverse effect on behaviour and physiology (Sneddon et al., 2003). When first describing cutaneous nociceptors in rainbow trout, Sneddon (Sneddon, 2002) found that some trigeminal nociceptors innervating the facial region responded to topical application of $1.0 \%$ acetic acid. However, Ashley et al. (Ashley et al., 2007) applied acetic acid to chemoreceptors, and found no receptor response to $0.1 \%$ and $0.5 \%$ acetic acid. These findings demonstrate that the chemosensory receptors of trout are activated to some degree by acetic acid and possibly in a concentration- 
dependent manner. However, a full stimulus-response relationship has not been characterised.

Determining what chemicals may evoke a nociceptive response in fish may have applied relevance; poor water quality is a common problem for fish reared in captivity (Huntingford et al., 2006), and acid rain and other forms of pollution increasingly affect free-living fish (Swackhamer, 2005; Krajick, 2001; Mason et al., 1996). Further understanding of the agents that activate nociceptor afferents, and hence may be potentially painful to fish, could inform both environmental and captive water quality regulations. The first aim of the present study was to establish whether polymodal nociceptors $(\mathrm{P})$ and mechanically sensitive chemoreceptors (M) exhibit a classic, concentration-dependent stimulus-response relationship to a potentially noxious chemical irritant, acetic acid. We predicted that receptor activity would be increased by increasing acid concentration (Carstens et al., 1998; Jones et al., 2004). A second aim was to determine whether trigeminal chemosensory afferents in rainbow trout respond to a range of chemical agents and are simply chemoreceptors, or whether they are only responsive to potentially noxious chemical irritants known to excite nociceptors in other vertebrate groups and, therefore, are likely to have a nociceptive function.

Acetic acid was chosen as this algesic has been validated as a noxious stimulus in trout (Sneddon, 2002; Sneddon, 2003; Sneddon et al., 2003; Ashley et al., 2006; Ashley et al., 2007). Increasing concentrations of acetic acid were applied to the receptive fields of polymodal nociceptors and mechanochemical afferents. Several other agents considered noxious (chemical irritants) or non-noxious were also used to explore specificity to noxious stimuli. Non-noxious agents were alarm pheromone, ammonium chloride, bile, fresh water and sodium bicarbonate. Chemical irritants were carbonated water (in the form of $\mathrm{CO}_{2}$-infused water, soda water and mineral water), citric acid, citric acid phosphate buffer and sodium chloride. Of particular interest is $\mathrm{CO}_{2}$ because hypercarbia results in major changes in fish cardiovascular responses but may also cause a peripheral acidosis that excites the free nerve endings of nociceptors. Trigeminally innervated $\mathrm{CO}_{2}$ receptors have been characterised in the orobranchial cavity of fish (Perry and Reid, 2002; Gilmour et al., 2005; Reid et al., 2005), but have not been recorded peripherally on the skin.

\section{MATERIALS AND METHODS Subjects}

Female rainbow trout, O. mykiss (mean mass $299 \pm 133 \mathrm{~g}$ ), were obtained from a commercial supplier and transferred to the aquarium at the University of Liverpool. The use of females eliminated any confounding effects of gender. Fish were housed in a stock tank $(1.5 \times 0.6 \times 1.0 \mathrm{~m} ; N=45$ fish per tank). This semi-closed system was maintained under an $11 \mathrm{~h}: 13 \mathrm{~h}$ light:dark regime with a constant flow of filtered freshwater at $12 \pm 1{ }^{\circ} \mathrm{C}$, and aeration was provided via a compressed air supply. The fish were fed with a commercial trout feed (Skretting, Northwich, UK) at $1 \%$ body mass per day. Experiments were only performed once fish had been allowed at least 2 weeks to recover from the stress of transport and demonstrated consistent feeding.

\section{Surgical procedure}

Experiments were conducted in a humane manner approved by the University of Liverpool's Ethics Committee and under a UK Home Office Licence. Fish were caught individually by netting, anaesthetised by immersion in benzocaine-dosed water $\left(1 \mathrm{mll}^{-1}\right.$, the benzocaine having first been dissolved in ethanol at $33 \mathrm{gl}^{-1}$; SigmaAldrich, Poole, UK), and weighed to the nearest $5 \mathrm{~g}$. The fish was then transferred to a purpose-built stainless steel cradle padded with foam. Wet paper towels were placed over the fish and it was held in position using Velcro ${ }^{\circledR}$ straps. Fish were ventilated by directing benzocaine-dosed ( $\sim 0.85 \mathrm{mll}^{-1}$ of $33 \mathrm{gl}^{-1}$ ethanol solution) water across the gills via a purpose-built mouthpiece at $750 \mathrm{ml} \mathrm{min}^{-1}$, thus maintaining surgical plane anaesthesia (McFarland, 1959). This water was kept at $12 \pm 1^{\circ} \mathrm{C}$ and aerated via an air stone and pump. The level of anaesthesia was determined by monitoring heart rate, ventilation rate and absence of reflexes. A constant flow of freshwater $\left(3 \mathrm{ml} \mathrm{min}^{-1}\right)$ was directed over the face of the trout to prevent the anaesthetic coming into contact with the skin. The brain was exposed by removal of cranial skin, cartilage and bone, and then decerebration was performed by removal of the olfactory and optic lobes via suction. Pavulon (Pancuronium bromide, $2 \mathrm{mg} \mathrm{ml}^{-1}$; Sigma-Aldrich), a neuromuscular blocker, was injected intramuscularly $\left(0.8 \mathrm{ml} \mathrm{kg}^{-1}\right)$ to prevent muscular twitching. Further tissue was then removed from the left lateral braincase to expose the left trigeminal ganglion, which was then desheathed.

\section{Electrophysiological recording}

Glass insulated tungsten electrodes (tip diameter $10 \mu \mathrm{m}$, impedance ca. $200 \mathrm{k} \Omega$; Royem Scientific Ltd, Luton, UK) were used to record extracellularly from afferent cell bodies in the trigeminal ganglion. Action potentials were amplified using an NL100 head stage connected to an NL104 pre-amplifier and signals were filtered using an NL125 filter (Neurolog System, Digitimer Ltd, Welwyn Garden City, UK). The signal was displayed on a storage oscilloscope (DSO 400 , Gould, Eichstetten, Germany) and the output was also sent to an NL120S audio amplifier (Neurolog System, Digitimer Ltd.) and a speaker. Data were stored and saved to a PC using a micro 1401 analogue-to-digital interface and Spike2 software (Cambridge Electronic Design, Cambridge, UK).

\section{Stimulus responses of polymodal and mechanochemical receptors}

Stimulus-evoked neural activity was recorded from single cells in the trigeminal ganglion. A glass probe ( $1.0 \mathrm{~mm}$ diameter) was lightly applied to the skin around the facial area to locate receptive fields, and the position of the receptor was mapped. A drop of $15 \mu \mathrm{l}$ of commercially available carbonated mineral water and/or $1.0 \%$ acetic acid was then applied successively to the receptor, using a pipette (Sealpette 5-50, Jencons, East Grinstead, UK), to determine chemical sensitivity, with freshwater rinses in between the two stimuli. After a chemically sensitive receptive field was located, its diameter was measured to the nearest $0.1 \mathrm{~mm}$ using Vernier callipers. Thermal sensitivity was measured using a custom-built Peltierdriven thermode with a $1 \mathrm{~mm}$ diameter flat contact point. This was placed on the receptive field and the temperature was increased steadily from 10 to $44^{\circ} \mathrm{C}$, using a thermocouple attached to the contact point and a driver feedback circuit. Threshold responses were established by repeating each measurement three times. Those receptors responding to mechanical stimulation in a slowly adapting manner, responsive to heat and to chemical stimuli, were classified as polymodal nociceptors, and those only responsive to mechanical and chemical stimulation were classified as mechanochemical receptors. To determine the concentration-dependent response to acetic acid, single $15 \mu \mathrm{l}$ drops of acetic acid at different concentrations (shown in Table 1) were placed onto the skin at the centre of the receptive field. Stimulation was repeated three times to determine whether responses to the agents were repeatable. Receptors were washed thoroughly with freshwater between applications. Occasionally, receptors were lost during recording; hence not all concentrations were tested on all receptors. 
Table 1. Properties of the chemical stimuli used to assess the chemosensitivity of the peripheral receptors around the facial region of rainbow trout using extracellular recording from afferent neurons in the trigeminal ganglion

\begin{tabular}{|c|c|c|}
\hline Agent & Concentration & $\mathrm{pH}$ \\
\hline \multirow[t]{6}{*}{ Acetic acid } & $0.5 \%$ & 3.0 \\
\hline & $0.6 \%$ & 2.9 \\
\hline & $0.8 \%$ & 2.9 \\
\hline & $1.0 \%$ & 2.8 \\
\hline & $1.2 \%$ & 2.8 \\
\hline & $1.4 \%$ & 2.7 \\
\hline Alarm pheromone & - & - \\
\hline \multirow[t]{4}{*}{ Ammonium chloride } & $0.02 \mathrm{mgl}^{-1}$ & 6.0 \\
\hline & $0.1 \mathrm{mg} \mathrm{l}^{-1}$ & 6.4 \\
\hline & $0.5 \mathrm{mgl}^{-1}$ & 6.5 \\
\hline & $1.0 \mathrm{mgl}^{-1}$ & 6.5 \\
\hline Bile & - & - \\
\hline Carbonated mineral water & - & 4.8 \\
\hline \multirow[t]{3}{*}{ Citric acid } & $0.5 \%$ & 2.5 \\
\hline & $1.0 \%$ & 2.3 \\
\hline & $2.0 \%$ & 2.3 \\
\hline \multirow[t]{5}{*}{ Citric acid phosphate buffer } & $\mathrm{pH} 3$ & 3.0 \\
\hline & $\mathrm{pH} 4$ & 4.0 \\
\hline & $\mathrm{pH} 5$ & 5.0 \\
\hline & $\mathrm{pH} 6$ & 6.0 \\
\hline & $\mathrm{pH} 7$ & 7.0 \\
\hline $\mathrm{CO}_{2}$ water & $1.4 \mathrm{gl}^{-1}$ & 3.8 \\
\hline Freshwater & - & $6.5-7.0$ \\
\hline Soda water & $7.4-8.1 \mathrm{gl}^{-1}$ & 5.2 \\
\hline \multirow[t]{3}{*}{ Sodium bicarbonate } & $0.1 \mathrm{moll}^{-1}$ & 8.6 \\
\hline & $0.5 \mathrm{moll}^{-1}$ & 9.2 \\
\hline & $1.0 \mathrm{moll}^{-1}$ & 9.5 \\
\hline \multirow[t]{4}{*}{ Sodium chloride } & $0.5 \mathrm{moll}^{-1}$ & - \\
\hline & $1.0 \mathrm{moll}^{-1}$ & - \\
\hline & $2.0 \mathrm{moll}^{-1}$ & - \\
\hline & $5.0 \mathrm{moll}^{-1}$ & - \\
\hline
\end{tabular}

\section{Chemosensitive receptor responses to different agents}

To determine whether the chemoreceptors responded to any chemical or were nociceptive, several agents were assessed, as shown in Table 1. Alarm pheromone was chosen as a non-noxious stimulus that would be expected to induce an olfactory response in fish but not excite nociceptors (Sorensen and Caprio, 1998). Bile was chosen because bile acids are important odorants to which fish show both olfactory and gustatory sensitivity but would not be nociceptive (Hara, 1994; Sorensen and Caprio, 1998). Ammonium chloride at high concentrations is toxic to teleosts, but concentrations between 0.02 and $1.0 \mathrm{mg} \mathrm{l}^{-1}$ were tested - levels that are assumed to be non-irritating to trout (Hedtke and Norris, 1980; Holliman, 1993; Saha and Ratha, 1994; Craig and Laming, 2004). Sodium bicarbonate was also tested (at $0.1,0.5$ and $1.0 \mathrm{moll}^{-1}$ ) because alkaline waters can have deleterious effects on fish physiology but several studies have shown that rainbow trout can adapt and survive in high $\mathrm{pH}$ environments, an event that can occur naturally in eutrophic lakes (Yesaki and Iwama, 1992; Wilkie and Wood, 1994; Wilkie et al., 1996). High $\mathrm{pH}$ has not been reported to excite nociceptors in other vertebrates (Galea, 2002; Woolf and Ma, 2007; Dafny, 2010). Thus, sodium bicarbonate was utilised as an alkali that would not be expected to excite nociceptors. Normal freshwater (taken from the fish's holding water) was also applied to each receptor as a neutral control stimulus.

Acetic acid has been validated as a noxious stimulus in trout (Sneddon, 2002; Sneddon, 2003; Sneddon et al., 2003; Ashley et al., 2006; Ashley et al., 2007), and has been used in various studies in other species (McKeegan, 2004; Belmonte et al., 1991). Carbonated mineral water (San Pellegrino) was chosen because carbon dioxide $\left(\mathrm{CO}_{2}\right)$ has been suggested to be a purely trigeminal irritant (Silver and Maruniak, 1981) and commercially available carbonated water was used by Carstens et al. (Carstens et al., 1998) in a study investigating mechanisms of irritation in rat mucosa. Soda water is made from normal tap water rather than mineral water, but it has an alkaline compound added (sodium bicarbonate) to neutralize it prior to carbonation and it contains a higher volume of $\mathrm{CO}_{2}$ than carbonated mineral waters (Mitchell, 1990). Thus, it was applied as a more concentrated form of $\mathrm{CO}_{2}\left(7.4-8.1 \mathrm{gl}^{-1} \mathrm{CO}_{2}\right.$ at $25^{\circ} \mathrm{C}$; Tesco, Cheshunt, UK). A more dilute source of $\mathrm{CO}_{2}$ was also used, prepared on site by bubbling $\mathrm{CO}_{2}$ gas through deionised water $\left(1.4 \mathrm{gl}^{-1} \mathrm{CO}_{2}\right.$ at $\left.25^{\circ} \mathrm{C}\right)$.

Carstens et al. (Carstens et al., 1998) demonstrated that trigeminal receptors in rats responded to $\mathrm{pH}$ in a concentration-dependent manner, so a series of $\mathrm{pH}$ buffers was used ( $\mathrm{pH} 3$ to 7 ) to determine the effect of decreasing $\mathrm{pH}$ on receptors. As citric acid phosphate buffer was used for this, we decided to test citric acid as well at 0.5 , 1.0 and $2.0 \%$, concentrations similar to those found to be noxious in human oral mucosa (Gilmore and Green, 1993). In this experiment, sodium chloride $(\mathrm{NaCl})$ was also investigated as noxious because $0.6 \mathrm{moll}^{-1} \mathrm{NaCl}$ excited corneal receptors in the cat with a more pronounced response than acetic acid (Belmonte et al., 1991). For this reason, $\mathrm{NaCl}$ was tested at $0.5,1.0,2.0$ and $5.0 \mathrm{moll}^{-1}$.

Chemically sensitive receptive fields were located as described above. To measure chemosensitivity, single $15 \mu \mathrm{l}$ drops of the various agents, at the different concentrations, were placed onto the skin at the centre of the receptive field. Again, stimulation was repeated three times to confirm that responses were repeatable. Receptors were washed thoroughly with freshwater between applications. To prevent anomalous findings caused by damage to the skin and/or receptor, not all agents and/or concentrations were applied to all receptors. For any one receptor, a random selection of agents was tested and the agents were applied in random order, with the exception of 1.2 and $1.4 \%$ acetic acid, which were observed to cause visible skin damage and so were applied last. However, occasionally receptors were lost during recording; hence not all concentrations were tested on all receptors. Nonetheless, three key agents were always assessed where possible: carbonated mineral water (noxious) and/or 1\% acetic acid (noxious) and freshwater as a control.

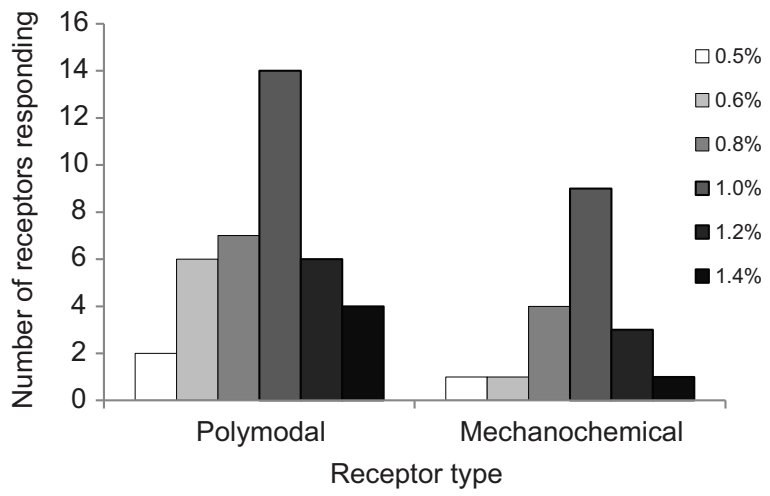

Fig. 1. Comparison of the number of polymodal $(P)$ and mechanochemical (M) trigeminal afferents that responded to the application of a $15 \mu \mathrm{l}$ drop of various concentrations of acetic acid. Total afferents responding: $0.5 \%$

$(N=7 \mathrm{P}, N=3 \mathrm{M}), 0.6 \%(N=8 \mathrm{P}, N=5 \mathrm{M}), 0.8 \%(N=8 \mathrm{P}, N=9 \mathrm{M}), 1.0 \%(N=14$ $\mathrm{P}, N=9 \mathrm{M}), 1.2 \%(N=8 \mathrm{P}, N=9 \mathrm{M})$ and $1.4 \%(N=6 \mathrm{P}, N=3 \mathrm{M})$. 

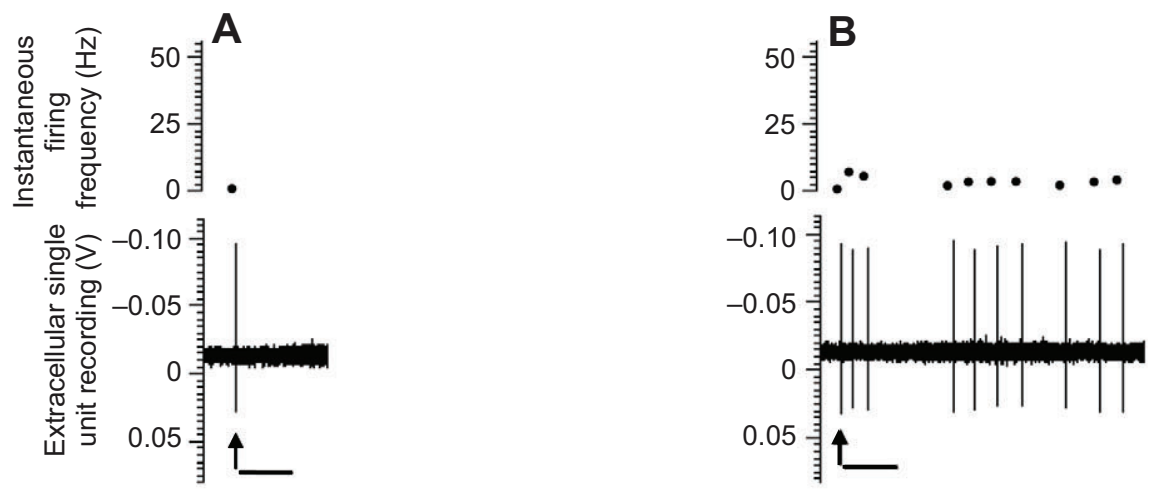

Fig. 2. Response of a trigeminal polymodal afferent to topical application of $15 \mu \mathrm{l}$ drops of various concentrations of acetic acid. For each recording, the upper trace plots the instantaneous firing frequency and the lower the extracellular single unit recording from the trigeminal ganglion. (A) $0.5 \%$; (B) $0.6 \%$; (C) $0.8 \%$; (D) $1.0 \%$; (E) $1.2 \%$; (F) $1.4 \%$. Arrows show the point of stimulus application.
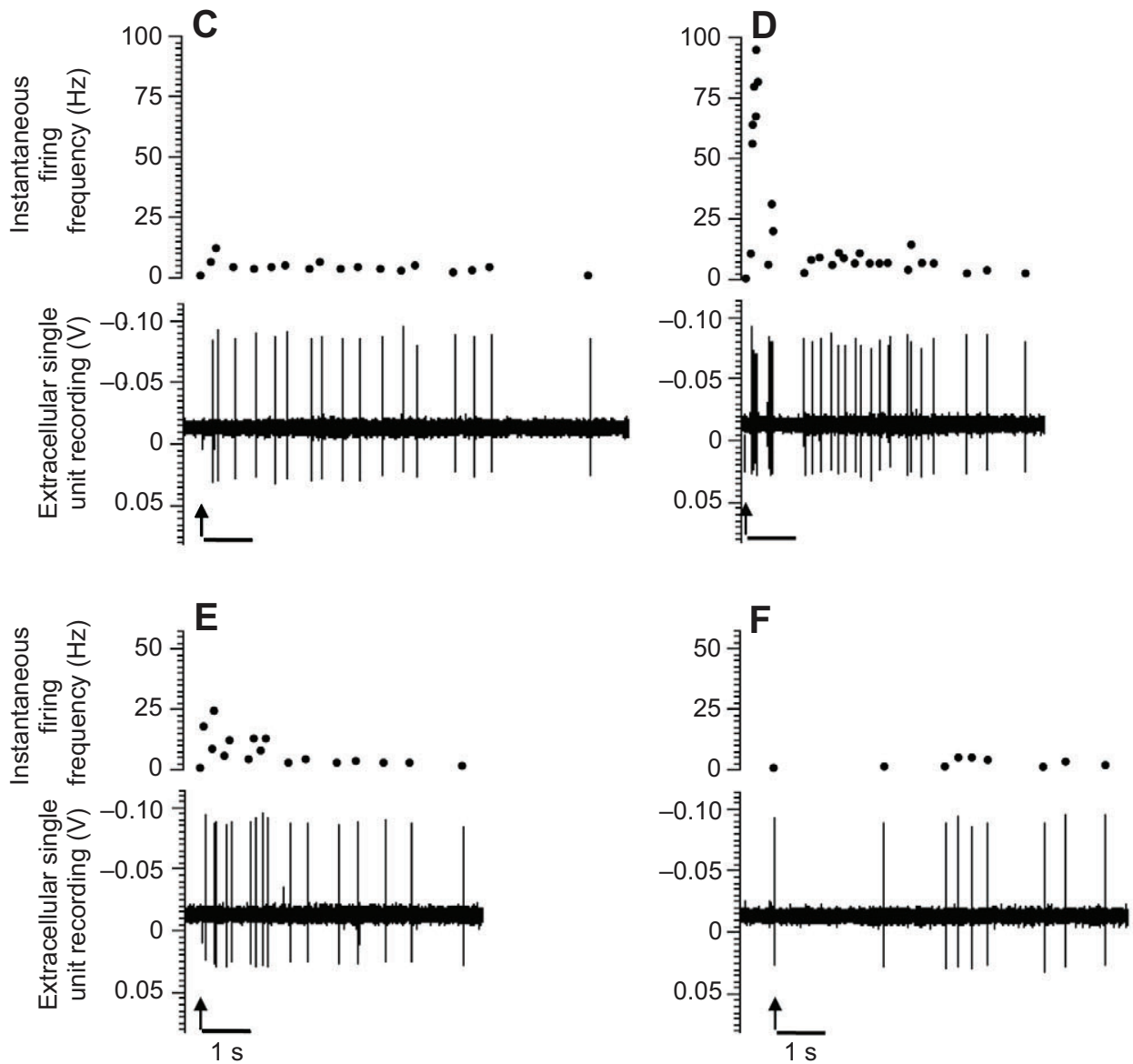

The alarm pheromone was produced from rainbow trout skin using a behaviourally validated method (Ashley et al., 2009). It was extracted by skinning humanely killed trout, rinsing the skin with deionised water and cutting it with a razor to damage the cells. Approximately $35 \mathrm{~g}$ of skin was then placed into a $50 \mathrm{ml}$ tube containing $25-30 \mathrm{ml}$ of deionised, sterile water, which was kept chilled on ice. The mixture was then homogenised and centrifuged for $15 \mathrm{~min}$ at $3500 \mathrm{~g}$ at $4^{\circ} \mathrm{C}$. The supernatant was extracted, filtered to remove debris, placed in a clean $50 \mathrm{ml}$ tube and frozen at $20^{\circ} \mathrm{C}$ (Ashley et al., 2009). Samples were defrosted and allowed to warm to room temperature before use. The bile was taken from these trout directly from the gall bladder with a $25 \mathrm{G} 1 \mathrm{inch}$ disposable needle and $1 \mathrm{ml}$ disposable syringe following abdominal incision to access the organ (Andréasson and Dave, 1995). Bile was frozen for storage then defrosted and diluted $(20 \times)$ with distilled water prior to use.

\section{Spike2 analysis}

Several action potential parameters were measured using Spike2 software: action potential amplitude, action potential duration, and afterhyperpolarisation amplitude and duration.

\section{Statistical analysis}

Data were tested for normality prior to analysis to determine whether non-parametric or parametric tests should be applied. All analyses and data used the response to the first application of an agent. If a receptor demonstrated no response to an agent at one concentration, but had responded to that agent at another concentration, values for the non-responding concentration were taken to be zero. All statistics were calculated using SPSS Version 15 (IBM, Portsmouth, UK).

In the stimulus-response experiment, the properties of polymodal and mechanochemical receptors were analysed using Mann-Whitney $U$-tests comparing the receptive field diameters, 
action potentials, and afterhyperpolarisation amplitudes and durations. Comparisons between polymodal and mechanochemical receptor responses to acetic acid were also determined using Mann-Whitney $U$-tests.

\section{RESULTS}

\section{Stimulus response to acetic acid}

Of 23 fully characterised chemosensitive receptors, 14 were polymodal $(\mathrm{P})$, responding to mechanical stimulation, noxious heat and chemical stimulation (acetic acid), and nine were mechanochemical $(\mathrm{M})$, responding only to mechanical and chemical stimulation. The two classes of afferents were compared for their receptive field and electrophysiological characteristics. Other than the duration of the extracellularly recorded action potentials, which was significantly greater for $\mathrm{P}$ than for $\mathrm{M}$ afferents (mean 3.27 \pm 0.22 vs $2.42 \pm 0.50 \mathrm{~ms} ; P=0.006$ ), there were no significant differences between the two types. Both receptor types were evenly distributed across the regions of the face and upper lip that were accessible for testing. Concentration-dependent responses to acetic acid showed similar 'bell-shaped' configurations for both receptor types, with the majority of both $\mathrm{P}$ and $\mathrm{M}$ receptors responding to $1.0 \%$ acetic acid (Fig. 1) and fewer responding to the other concentrations. No differences between $\mathrm{P}$ and $\mathrm{M}$ afferents were observed in the latency to respond or the total number of action potentials generated for any of the concentrations tested. An example of a $\mathrm{P}$ afferent responding to all concentrations is shown in Fig. 2.

\section{Responses to innocuous chemicals and chemical irritants}

A total of 89 afferents responded to stimulation with either $1.0 \%$ acetic acid and/or carbonated mineral water and were further studied for their response to other irritant and innocuous chemicals. As electrophysiological responses and concentration-dependent response relationships of $\mathrm{P}$ and $\mathrm{M}$ receptors to acetic acid had already been shown to be similar, all chemically sensitive afferents were pooled to increase sample size.

A summary of the numbers of chemosensitive afferents that responded to each of the agents and the different concentrations at which responses were seen is presented in Table2. Some agents did not trigger a response from any of the receptors to which they were applied. These were alarm pheromone, ammonium chloride (at four concentrations), bile, freshwater and sodium bicarbonate (three concentrations). Acetic acid stimulated some of the afferents, ranging from $33 \%(0.5 \%$ acetic acid) to a maximum of $77 \%(1.0 \%$ acetic acid) responding. All afferents responded to carbonated mineral water and soda water, but $\mathrm{CO}_{2}$-infused water activated only $87 \%$ of those to which it was applied. Citric acid stimulated some of the afferents, ranging from $0 \%(0.5 \%$ citric acid $)$ to a maximum of $71 \%(2.0 \%$ citric acid). The response to citric acid phosphate buffers ranged from $8 \%(\mathrm{pH} 7)$ to $62 \%$ of afferents responding $(\mathrm{pH} 3)$, and the response to sodium chloride $(\mathrm{NaCl})$ ranged from $7 \%\left(0.5 \mathrm{moll}^{-1}\right)$ to a maximum of $77 \%\left(5.0 \mathrm{moll}^{-1}\right)$ of those tested.

The distribution of the receptors that responded to various agents was evenly spread across the area tested. Three or more agents considered noxious were tested on 26 chemically responsive receptors; seven only responded to one agent, four responded to two and 15 responded to three or more (Table 3 ). Afferents that responded to only one agent were all stimulated by carbonated water. Those responding to two agents responded to carbonated water and acetic acid (but these four receptors were only tested with carbonated water, acetic acid and $\mathrm{pH}$ ). Of the 15 afferents that responded to three or more agents, all were stimulated by carbonated water and acetic acid as well as one, two or three of the other agents applied,
Table 2. Response to chemical agents by chemosensitive receptors on the face of rainbow trout using extracellular recording from afferent neurons in the trigeminal ganglion

\begin{tabular}{|c|c|c|}
\hline Agent & Concentration & $\begin{array}{l}\text { Number of afferents } \\
\text { responding (total tested) }\end{array}$ \\
\hline \multirow[t]{6}{*}{ Acetic acid } & $0.5 \%$ & $4(12)$ \\
\hline & $0.6 \%$ & $10(17)$ \\
\hline & $0.8 \%$ & $12(24)$ \\
\hline & $1.0 \%$ & $34(44)$ \\
\hline & $1.2 \%$ & $12(26)$ \\
\hline & $1.4 \%$ & $5(12)$ \\
\hline Alarm pheromone & - & $0(22)$ \\
\hline \multirow[t]{4}{*}{ Ammonium chloride } & $0.02 \mathrm{mgl}^{-1}$ & $0(10)$ \\
\hline & $0.1 \mathrm{mgl}^{-1}$ & $0(10)$ \\
\hline & $0.5 \mathrm{mgl}^{-1}$ & $0(10)$ \\
\hline & $1.0 \mathrm{mgl}^{-1}$ & $0(10)$ \\
\hline Bile & - & $0(23)$ \\
\hline Carbonated mineral water & - & $41(41)$ \\
\hline $\mathrm{CO}_{2}$ water & - & $13(15)$ \\
\hline Soda water & - & $16(16)$ \\
\hline \multirow[t]{3}{*}{ Citric acid } & $0.5 \%$ & $0(7)$ \\
\hline & $1.0 \%$ & $2(7)$ \\
\hline & $2.0 \%$ & $5(7)$ \\
\hline \multirow[t]{5}{*}{ Citric acid phosphate buffer } & $\mathrm{pH} 3$ & $8(13)$ \\
\hline & $\mathrm{pH} 4$ & $3(13)$ \\
\hline & $\mathrm{pH} 5$ & $5(23)$ \\
\hline & $\mathrm{pH} 6$ & $1(11)$ \\
\hline & $\mathrm{pH} 7$ & $1(12)$ \\
\hline Freshwater & - & $0(40)$ \\
\hline \multirow[t]{3}{*}{ Sodium bicarbonate } & $0.1 \mathrm{moll}^{-1}$ & $0(7)$ \\
\hline & $0.5 \mathrm{moll}^{-1}$ & $0(7)$ \\
\hline & $1.0 \mathrm{moll}^{-1}$ & $0(7)$ \\
\hline \multirow[t]{4}{*}{ Sodium chloride } & $0.5 \mathrm{moll}^{-1}$ & $1(14)$ \\
\hline & $1.0 \mathrm{moll}^{-1}$ & $1(13)$ \\
\hline & $2.0 \mathrm{moll}^{-1}$ & $3(13)$ \\
\hline & $5.0 \mathrm{moll}^{-1}$ & $10(13)$ \\
\hline
\end{tabular}

with no apparent pattern in which of the other agents would evoke a response. Examples of a single chemosensitive afferent's responses to different agents are shown in Fig. 3 (citric acid phosphate buffer was not applied to this receptor, so a response to this agent is not shown).

\section{DISCUSSION}

Polymodal (P) and mechanochemical (M) receptors displayed similar electrophysiological properties. Both responded to acetic acid in a similar, concentration-dependent manner and showed similar response characteristics to stimulation with acetic acid. For this reason, data for the two receptor types were pooled for the second experiment. Chemically responsive receptors did not respond to any of the innocuous chemicals - alarm pheromone, ammonium chloride, bile, freshwater and sodium bicarbonate (Holliman, 1993; Hara, 1994; Sorensen and Caprio, 1998; Craig and Laming, 2004; Galea, 2002; Wilkie et al., 1996) - suggesting that they have a purely nociceptive function. These mechanochemical receptors responded to between one and five (all of the potentially noxious agents tested) types of agent. Those responding to just one irritant responded to carbonated water whereas those responding to two types were stimulated by both carbonated water and acetic acid. Those receptors that responded to three or more agents showed no apparent trend; therefore, specificity needs to be explored in future studies.

Although every effort was made to avoid direct contact between the local anaesthetic and recording areas, it is possible that this could have affected the afferent responses recorded during the experiment. 
Table 3. The incidence of individual chemosensitive trigeminal afferent responses to application of various agents (acetic acid at concentrations of $0.5,0.6,0.8,1.0,1.2$ and $1.4 \%$; citric acid at concentrations of $0.5,1.0$ and $2.0 \% ; \mathrm{pH}$ at 3.0, 4.0, 5.0, 6.0 and 7.0; and sodium chloride at concentrations of $0.5,1.0,2.0$ and $5.0 \mathrm{moll}^{-1}$ )

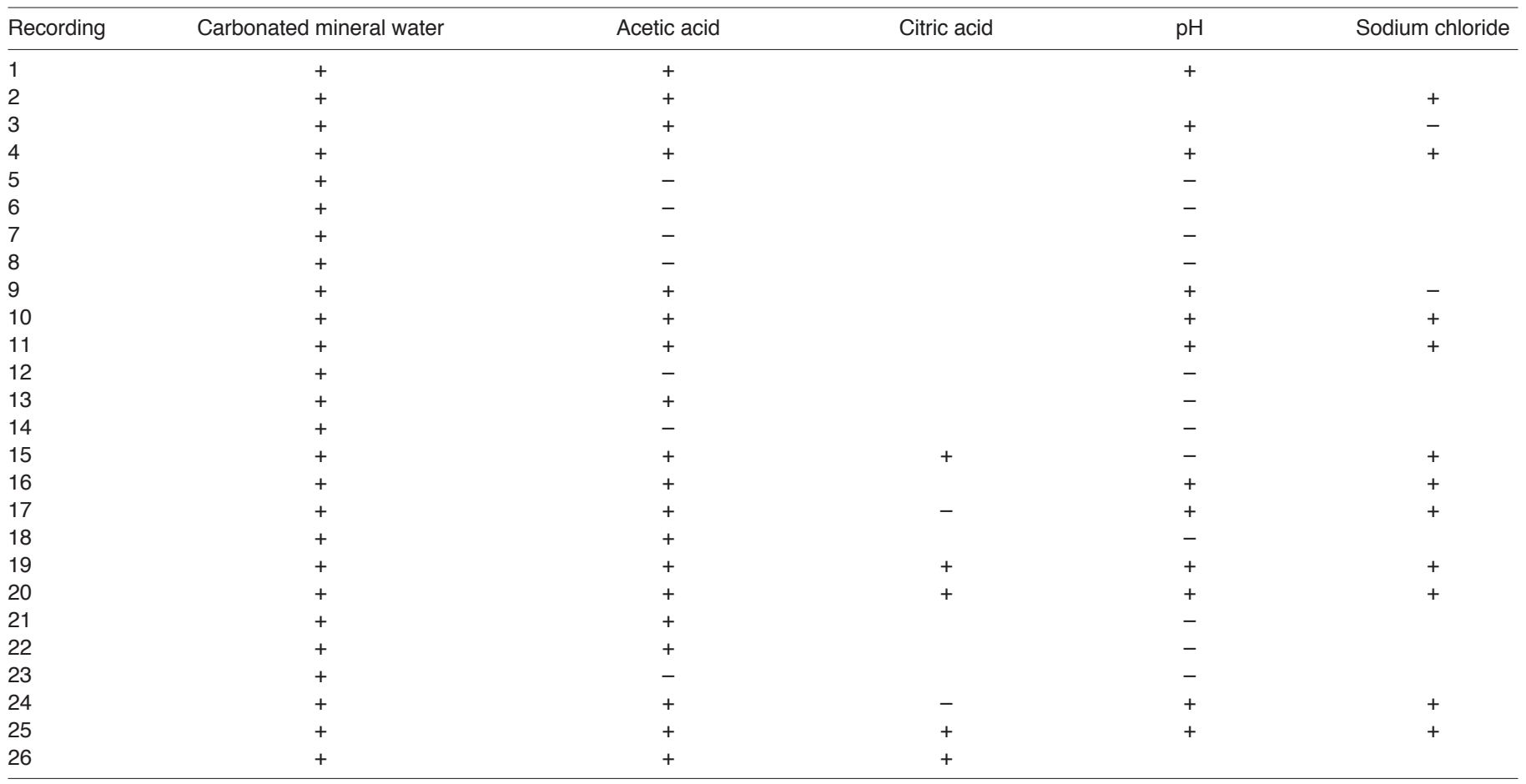

+ , Positive response to at least one concentration of the applied agent; -, no response to any concentration of applied agent; blank, agent not applied.

However, responses of $\mathrm{P}$ and $\mathrm{M}$ afferents were similar to those recorded in previous studies that used an injectable anaesthetic,

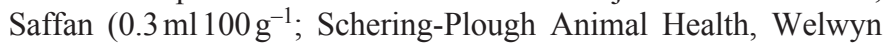
Garden City, UK) (Sneddon, 2002; Sneddon, 2003; Sneddon et al., 2003; Ashley et al., 2007), making this unlikely.

\section{Stimulus response to acetic acid}

The general properties of $\mathrm{P}$ and $\mathrm{M}$ afferents were similar to those recorded by Sneddon and others (Sneddon, 2002; Sneddon, 2003; Sneddon et al., 2003; Ashley et al., 2007) in their studies of trout nociceptors. The only difference was the longer action potential duration of $\mathrm{P}$ afferents. In mammals, the action potential duration of $\mathrm{C}$ fibres is longer than that of $\mathrm{A} \delta$ fibres, but mammals also possess sub-populations of $A \delta$ neurons that demonstrate different action potential durations (López De Armentia et al., 2000). Thus, the longer action potential duration of $\mathrm{P}$ afferents is of interest as it may suggest that trout $\mathrm{P}$ receptors include a higher proportion of $\mathrm{C}$ fibres and/or a different sub-population of A $\delta$ fibres than $M$ receptors. In mammals, $\mathrm{C}$ fibres (polymodal receptors) tend to be involved in more prolonged nociceptive stimulation whereas $A \delta$ fibres (mechanothermal receptors) mediate more acute responses; however, because $\mathrm{C}$ fibres in trout are rare [4\% total fibre type (Sneddon, 2002; Sneddon, 2003)], the longer action potentials were more likely due to a different sub-population of $A \delta$ fibres to $M$ receptors.

Acid sensitivity has physiological relevance as tissue acidosis occurs during various pathological conditions, including inflammation and ischaemia, and exogenous acids have the potential to cause physical damage (Jones et al., 2004). In the present study, both $\mathrm{P}$ and $\mathrm{M}$ receptors responded to acetic acid in a concentrationdependent manner, with maximal responses observed at $1.0 \%$. Hamamoto and Simone (Hamamoto and Simone, 2003) found that primary afferent fibres in frogs responded to acetic acid in the same way and suggested that the receptors were desensitised to the agent above a certain concentration.

Responses to innocuous chemicals and chemical irritants The results of this and previous studies (Sneddon, 2002; Sneddon, 2003; Sneddon et al., 2003; Ashley et al., 2006; Ashley et al., 2007) support a nociceptive function for trigeminally innervated mechanochemical receptors, so we have termed them nociceptors. The chemical irritants used here are known to excite nociceptors in other vertebrates [e.g. amphibians (Hamamoto et al., 2000), birds (McKeegan, 2004) and mammals (Belmonte et al., 1991)]. The trout chemosensitive receptors were stimulated by different preparations of carbonated water at varying $\mathrm{pHs}$, as has been recorded for $\mathrm{CO}_{2}$ receptors located on the first gill arch of fish (Gilmour et al., 2005). In mammals, there is now strong evidence that nociceptor activation by carbonated solutions is due to the conversion of $\mathrm{CO}_{2}$ to carbonic acid via the enzyme carbonic anhydrase (Dessirier et al., 2000; Simons et al., 1999), the same mechanism by which $\mathrm{CO}_{2}$ gas is thought to activate nociceptors (Hummel et al., 2003). Gaseous $\mathrm{CO}_{2}$ has been demonstrated to excite nociceptors in a concentrationdependent manner in higher vertebrates (Peppel and Anton, 1993; Chen et al., 1995; Acosta et al., 2001), and during the present study different types of carbonated solution were applied in a preliminary attempt to assess concentration-response relationships. $\mathrm{CO}_{2}$-infused deionised water has a lower $\mathrm{CO}_{2}$ content compared with the two other $\mathrm{CO}_{2}$ stimuli. However, all receptors tested responded to both mineral water and soda water so it is not possible to comment on whether the receptors were able to discriminate between these $\mathrm{CO}_{2}$ concentrations. A study by Peppel and Anton (Peppel and Anton, 1993) on the response of chemosensitive intra-nasal receptors to 

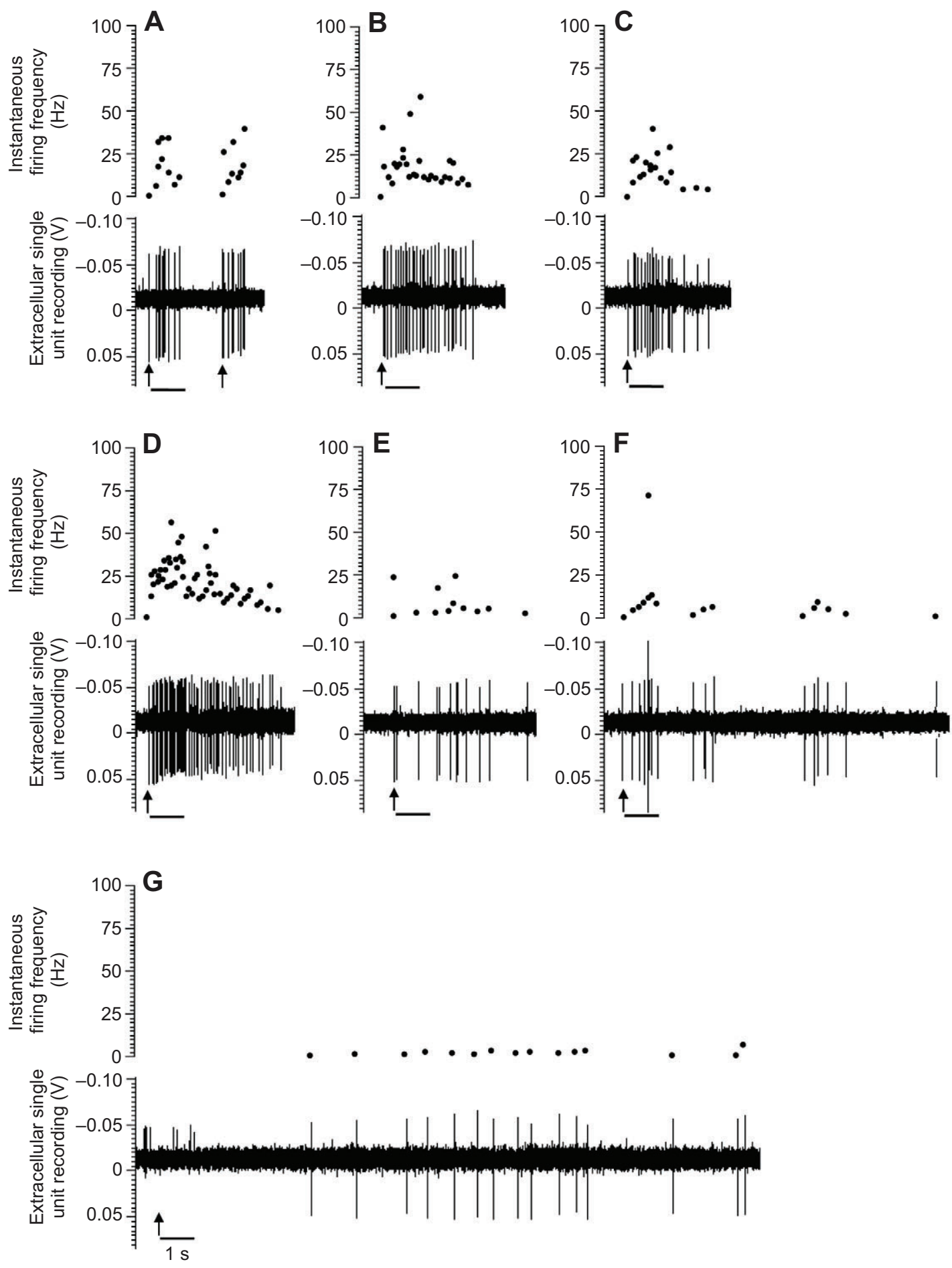

Fig. 3. Responses of a single trigeminal chemosensitive afferent to topical application of a $15 \mu \mathrm{l}$ drop of various agents. For each recording, the upper trace plots the instantaneous firing frequency and the lower the extracellular single unit recording from the trigeminal ganglion. (A) Mechanical stimulus created by twice applying a glass probe to the receptor; (B) carbonated mineral water; (C) $\mathrm{CO}_{2}$-infused distilled water; (D) soda water; (E) $1.0 \%$ acetic acid; (F) $2.0 \%$ citric acid; (G) $5.0 \mathrm{moll}^{-1}$ sodium chloride. The large action potential in the middle of trace $F$ and the small action potentials at the beginning of trace $G$ are spontaneous firing from other, nearby receptors. Arrows show the point of stimulus application.

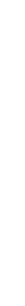

puffs of $\mathrm{CO}_{2}$ in the rat demonstrated that receptors had reduced capability to discriminate between the stimulus intensities at high $\mathrm{CO}_{2}$ concentrations, so it would be interesting to study this aspect of $\mathrm{CO}_{2}$ concentration further.

Hypercarbia has a profound effect on fish physiology and results in changes in ventilation, heart rate as well as alterations in blood pressure, cardiac output and systemic resistance (Gilmour et al., 2005; Reid et al., 2005). $\mathrm{CO}_{2}$ is detected by chemoreceptors located on the gill arches and/or in the orobranchial cavity and is innervated by the glossopharyngeal nerve and trigeminal and/or facial nerves, respectively. These receptors detect changes in external $\mathrm{CO}_{2}$ concentrations that influence physiological alterations (Taylor et al., 2010). However, to our knowledge this is the first identification of $\mathrm{CO}_{2}$-sensitive receptors on the head of a fish. Fish are known to avoid and swim away from elevated $\mathrm{CO}_{2}$ concentrations. Indeed, use of $\mathrm{CO}_{2}$ has been suggested as a method to move fish without handling (Clingerman et al., 2007; Summerfelt et al., 2009). $\mathrm{CO}_{2}$ has also been used as a method to anaesthetise and/or slaughter fish (Erikson et al., 2006; Poli et al., 2005). Current EU recommendations for farmed fish no longer advocate such use of $\mathrm{CO}_{2}$, except for emergency slaughter (http://www.coe.int), but outside the EU, $\mathrm{CO}_{2}$ is commonly in use (Yue, 2008). As some of the receptors in the 
present study responded to other noxious chemicals, this suggests that high $\mathrm{CO}_{2}$ levels may be potentially painful in trout. This would account for the strong aversive behaviour and flight reactions observed when fish are placed in $\mathrm{CO}_{2}$ saturated water (Yue, 2008; Poli et al., 2005; Southgate and Wall, 2001). Alternatively, these externally orientated $\mathrm{CO}_{2}$ receptors and indeed those that were only responsive to $\mathrm{CO}_{2}$ may provide the initial detection of elevated dissolved $\mathrm{CO}_{2}$ so that the fish can make an avoidance response prior to those on the gill arches and orobranchial cavity being stimulated to elicit a cardiovascular reaction. Future studies should test whether stimulating the facial $\mathrm{CO}_{2}$ receptors does have an impact upon ventilatory and cardiorespiratory measurements to understand their role in responses to hypercarbia.

The chemosensitive receptors also responded to $\mathrm{pH}$ buffers and citric acid, with more receptors responding to decreasing $\mathrm{pH}$ and increased concentration of citric acid. Acidic conditions (low water $\mathrm{pH}$ ) cause gill and epidermal damage in fish, leading to problems with osmoregulation and oxygen uptake (Branson, 1992). Higher concentrations of $\mathrm{NaCl}$ (hyperosmolarity) also activated more receptors, as reported for nociceptors in mammals (Green and Gelhard, 1989; Gilmore and Green, 1993; Carstens et al., 1998). It was suggested that such activation in mammals is, at least in part, mediated by capsaicin-sensitive receptors, via an amiloride-sensitive transduction mechanism (Dessirier et al., 2001).

The $\mathrm{pH}$ of $0.5 \%$ citric acid used here $(\mathrm{pH} 2.5)$ was as low as any of the acetic acid concentrations tested (2.8). It might, therefore, be expected that this concentration of citric acid would consistently stimulate the receptors if they were responding to low $\mathrm{pH}$, which it did not (the threshold for response to citric acid was approximately $1.0 \%$ ). This suggests that these responses were to the citrate ion rather than $\mathrm{pH}$. However, only one receptor that was not affected by decreasing $\mathrm{pH}$ responded to citric acid. This may be an anomaly or a rare subpopulation of receptors, and this could be further tested using sodium citrate. Studies on other vertebrate groups suggest that the osmolarity of an algesic chemical may affect nociception such that agents with high osmolarity may evoke receptor responses at a sub-threshold $\mathrm{pH}$ (Jensen and Norup, 1992; Hamamoto et al., 2000). The response of frogs to acetic acid is due to a combination of $\mathrm{pH}$ and osmolarity, and acetic acid has been found to induce a wiping response at the least acidic $\mathrm{pH}$ of a range of different acids (Hamamoto et al., 2000). As the trout chemosensitive receptors responded to both acidic and hyperosmolar agents in a manner similar to those recorded in higher vertebrates, it would indicate that similar mechanisms of activation may be involved. However, the exact nature of afferent responses to the $\mathrm{pH}$ and osmolarity of agents remains to be tested.

It is unlikely that fish are exposed to the high salt concentrations used during the experiment, nor is it likely that they would directly encounter the specific acidic chemical irritants used. However, low $\mathrm{pH}$ can be a problem both in fish culture and in wild populations, as a result of pollutants (Huntingford et al., 2006; Puste and Das, 2001). This can be a particular problem in re-circulating tank systems or where source water has low buffering capacity (Fivelstad et al., 2003; Walker and Whitaker, 1996). In ecosystems, industrial pollutants such as sulphur and nitrogen oxides cause acidification with marked effects on surface water pH (Krajick, 2001; Mason, 1994), and it has been reported that fish avoid areas of low $\mathrm{pH}$ (Havas and Rosseland, 1995). Of the nociceptive receptors that were exposed to three or more agents, the majority responded to multiple chemicals with fewer responding to one or two agents. These findings are consistent with studies of trigeminal receptors in higher vertebrates, which show that receptors may be activated by multiple irritants (Carstens et al., 1998; McKeegan, 2004; Belmonte et al., 1991; Sekizawa and Tsubone, 1994). Mammalian studies suggest that the multi-agent activation may to some degree be mediated via separate peripheral transduction mechanisms to tranduce a variety of chemical cues via a single receptor (Carstens et al., 1998; Belmonte et al., 1991).

In fish, four types of chemoreceptor system have been characterised: taste, olfaction, solitary chemoreceptor cells and free nerve endings (Finger, 1997). The free nerve endings mediate the 'common chemical sense' and are fibres with no specialist end organs that respond to irritant or noxious chemicals (Finger, 1997). As fish live in an aquatic environment, with exposure to many dissolved compounds, chemical sensitivity plays a major role in their biology, including during feeding, reproduction and migration. Future studies should test more environmentally relevant chemicals to determine their potential as chemical irritants and to understand the behavioural and physiological implications of exposure to such stimuli.

\section{ACKNOWLEDGEMENTS}

We are grateful to Jon Banks, who constructed the mechanical and thermal stimulators and provided technical assistance; to Richard Morris for the use of his laboratory and for technical advice; and to Paul Ashley for training J.M. in the electrophysiological techniques.

\section{FUNDING}

J.M. was supported by a Universities Federation for Animal Welfare (UFAW) Research Student Grant awarded to L.S. and C.R.M.

\section{REFERENCES}

Acosta, M. C., Belmonte, C. and Gallar, J. (2001). Sensory experiences in humans and single-unit activity in cats evoked by polymodal stimulation of the cornea. $J$. Physiol. 534, 511-525.

Andréasson, M. and Dave, G. (1995). Toxicity of bile from fish exposed to pentachlorophenol-spiked sediment. Mar. Environ. Res. 39, 335-339.

Ashley, P. J., Sneddon, L. U. and McCrohan, C. R. (2006). Properties of corneal receptors in a teleost fish. Neurosci. Lett. 410, 165-168.

Ashley, P. J., Sneddon, L. U. and McCrohan, C. R. (2007). Nociception in fish: stimulus-response properties of receptors on the head of trout Oncorhynchus mykiss. Brain Res. 1166, 47-54.

Ashley, P. J., Ringrose, S., Edwards, K. L., Wallington, E., McCrohan, C. R. and Sneddon, L. U. (2009). Effect of noxious stimulation upon antipredator responses and dominance status in rainbow trout. Anim. Behav. 77, 403-410.

Belmonte, C., Gallar, J., Pozo, M. A. and Rebollo, I. (1991). Excitation by irritant chemical substances of sensory afferent units in the cat's cornea. J. Physiol. 437, 709-725.

Branson, E. (1992). Environmental aspects of aquaculture. In Aquaculture for Veterinarians, 1st edn (ed. L. Brown), pp. 57-67. Oxford: Pergamon Press Ltd.

Carstens, E., Kuenzler, N. and Handwerker, H. O. (1998). Activation of neurons in rat trigeminal subnucleus caudalis by different irritant chemicals applied to oral or ocular mucosa. J. Neurophysiol. 80, 465-492.

Chen, X., Gallar, J., Pozo, M. A., Baeza, M. and Belmonte, C. (1995). $\mathrm{CO}_{2}$ stimulation of the cornea: a comparison between human sensation and nerve activity in polymodal nociceptive afferents of the cat. Eur. J. Neurosci. 7, 1154-1163.

Clingerman, J., Bebak, J., Mazik, P. M. and Summerfelt, S. T. (2007). Use of avoidance response by rainbow trout to carbon dioxide for fish self-transfer between tanks. Aquac. Engineer. 37, 234-251.

Craig, S. and Laming, P. (2004). Behaviour of the three-spined stickleback, Gasterosteous aculeatus (Gasterosteidae, Teleostei) in the multispecies freshwater biomonitor: a validation of automated recordings at three levels of ammonia pollution. Water Res. 38, 2144-2154.

Dafny, N. (2010). Pain principles. In Neuroscience Online (ed. J. Byrne). Houston, TX: The University of Texas Medical School.

Davis, K. D., Meyer, R. A. and Campbell, J. N. (1993). Chemosensitivity and sensitization of nociceptive afferents that innervate the hairy skin of monkey. $J$. Neurophysiol. 69, 1071-1081.

Dessirier, J.-M., Simons, C. T., Carstens, M. I., O'Mahony, M. and Carstens, E. (2000). Psychophysical and neurobiological evidence that the oral sensation elicited by carbonated water is of chemogenic origin. Chem. Senses 25, 277-284.

Dessirier, J.-M., O'mahony, M., lodi-Carstens, M., Yao, E. and Carstens, E. (2001) Oral irritation by sodium chloride: sensitization, self-desensitization, and crosssensitization to capsaicin. Physiol. Behav. 72, 317-324.

Erikson, U., Hultmann, L. and Steen, J. E. (2006). Live chilling of atlantic salmon (Salmo salar) combined with mild carbon dioxide anaesthesia: I. Establishing a method for large-scale processing of farmed fish. Aquaculture 252, 183-198.

Finger, T. E. (1997). Evolution of taste and solitary chemoreceptor cell systems. Brain Behav. Evol. 50, 234-243. 
Fivelstad, S., Waagbo, R., Zeitz, S. F., Hosfeld, A. C. D., Olsen, A. B. and Stefansson, S. (2003). A major water quality problem in smolt farms: combined effects of carbon dioxide, reduced $\mathrm{pH}$ and aluminum on atlantic salmon (Salmo salar L.) smolts: physiology and growth. Aquaculture 215, 339-357.

Folgueira, M., Anadon, R. and Yanez, J. (2003). Experimental study of the connections of the gustatory system in the rainbow trout, Oncorhynchus mykiss. J. Comp. Neurol. 465, 604-619.

Galea, M. P. (2002). Neuroanatomy of the nociceptive system. In Pain: a Textbook for Therapists, 4th edn (ed. J. Strong, A. M. Unruh, A. Wright and G. D. Baxter), pp. 1337. London: Churchill Livingston.

Gilmore, M. M. and Green, B. G. (1993). Sensory irritation and taste produced by $\mathrm{NaCl}$ and citric acid: effects of capsaicin desensitization. Chem. Senses 18, 257-272.

Gilmour, K. M., Milsom, W. K., Rantin, F. T., Reid, S. G. and Perry, S. F. (2005). Cardiorespiratory responses to hypercarbia in tambaqui Colossoma macropomum: chemoreceptor orientation and specificity. J. Exp. Biol. 208, 1095-1107.

Green, B. G. and Gelhard, B. (1989). Salt as an oral irritant. Chem. Senses 14, 259 271.

Hamamoto, D. T. and Simone, D. A. (2003). Characterization of cutaneous primary afferent fibers excited by acetic acid in a model of nociception in frogs. $J$. Neurophysiol. 90, 566-577.

Hamamoto, D. T., Forkey, M. W., Davis, W. L., Kajander, K. C. and Simone, D. A. (2000). The role of $\mathrm{pH}$ and osmolarity in evoking the acetic acid-induced wiping response in a model of nociception in frogs. Brain Res. 862, 217-229.

Hara, T. J. (1994). Olfaction and gustation in fish: an overview. Acta Physiol. Scand. 152, 207-217.

Havas, M. and Rosseland, B. O. (1995). Response of zooplankton, benthos, and fish to acidification: an overview. Water Air Soil Poll. 85, 51-62.

Hedtke, J. L. and Norris, L. A. (1980). Effect of ammonium-chloride on predatory consumption rates of brook trout (Salvelinus fontinalis) on juvenile chinook salmon (Oncorhynchus tshawytscha) in laboratory streams. Bull. Environ. Contam. Toxicol. 24, 81-89.

Holliman, A. (1993). The veterinary approach to trout. In Aquaculture for Veterinarians (ed. L. Brown), pp. 223-247. Oxford: Pergamon Press Ltd.

Hummel, T., Mohammadian, P., Marchl, R., Kobal, G. and Lötsch, J. (2003). Pain in the trigeminal system: irritation of the nasal mucosa using short- and long-lasting stimuli. Int. J. Psychophysiol. 47, 147-158.

Huntingford, F. A., Adams, C., Braithwaite, V. A., Kadri, S., Pottinger, T. G., Sandoe, P. and Turnbull, J. F. (2006). Current issues in fish welfare. J. Fish Biol. 68, 332-372.

Jensen, K. and Norup, M. (1992). Experimental pain in human temporal muscle induced by hypertonic saline, potassium and acidity. Cephalalgia 12, 101-106.

Jones, N. G., Slater, R., Cadiou, H., Mcnaughton, P. and McMahon, S. B. (2004) Acid-induced pain and its modulation in humans. J. Neurosci. 24, 10974-10979.

Krajick, K. (2001). Acid rain: long-term data show lingering effects from acid rain Science 292, 195-196.

Kumazawa, T. and Mizumura, K. (1980). Chemical responses of polymodal receptors of the scrotal contents in dogs. J. Physiol. 299, 219-231.

López De Armentia, M., Cabanes, C. and Belmonte, C. (2000). Electrophysiological properties of identified trigeminal ganglion neurons innervating the cornea of the mouse. Neurosci. 101, 1109-1115.

Mason, J. (1994). Acid rain - its effects on lakes, streams and fish. Renewable Energy 5, 1247-1253.

Mason, J. R., Nolte, D. L. and Bryant, B. P. (1996). Effectiveness of thirteen vertebrate repellents as rodent trigeminal stimulants. Physiol. Behav. 60, 1449-1452.

McFarland, W. M. (1959). A study of the effects of anaesthetics on the behaviour and physiology of fishes. Publ. Inst. Mar. Sci. Univ. Tex. 6, 23-55.

McKeegan, D. E. F. (2004). Mechano-chemical nociceptors in the avian trigemina mucosa. Brain Res. Rev. 46, 146-154.

McKeegan, D. E. F., Demmers, T. G. M., Wathes, C. M., Bryan Jones, R. and Gentle, M. J. (2002). Response characteristics of nasal trigeminal nociceptors in Gallus domesticus. NeuroReport 13, 1033-1035.

Mitchell, A. J. (1990). Carbonation and filling. In Formulation and production of carbonated soft drinks (ed. A. J. Mitchell), pp. 204-211. Glasgow: Blackie \& Son Ltd.
Peppel, P. and Anton, F. (1993). Responses of rat medullary dorsal horn neurons following intranasal noxious chemical stimulation: effects of stimulus intensity, duration, and interstimulus interval. J. Neurophysiol. 70, 2260-2275.

Perry, S. F. and Reid, S. G. (2002). Cardiorespiratory adjustments during hypercarbia in rainbow trout Oncorhynchus mykiss are initiated by external $\mathrm{CO}_{2}$ receptors on the first gill arch. J. Exp. Biol. 205, 3357-3365.

Poli, B. M., Parisi, G., Scappini, F. and Zampacavallo, G. (2005). Fish welfare and quality as affected by pre-slaughter and slaughter management. Aquac. Int. 13, 2949

Puste, A. M. and Das, D. K. (2001). Impact of air pollutant emissions on the ecosystems in the vicinity of industrial areas of indian sub-tropics. Water Air Soil Pollut. 130, 843-848.

Reid, S. G., Perry, S. E., Gilmour, K. A., Milsom, W. K. and Rantin, F. T. (2005) Reciprocal modulation of $\mathrm{O}_{2}$ and $\mathrm{CO}_{2}$ cardiorespiratory chemoreflexes in the tambaqui. Resp. Physiol. Neurobiol. 146, 175-194.

Saha, N. and Ratha, B. K. (1994). Induction of ornithine-urea cycle in a freshwate teleost, Heteropneustes fossilis, exposed to high concentrations of ammonium chloride. Comp. Biochem. Physiol. 108B, 315-325.

Sekizawa, S. I. and Tsubone, H. (1994). Nasal receptors responding to noxious chemical irritants. Respir. Physiol. 96, 37-48.

Sekizawa, S.-I., Tsubone, H., Kuwahara, M. and Sugano, S. (1998). Does histamine stimulate trigeminal nasal afferents? Respiration Physiol. 112, 13-22.

Silver, W. L. and Maruniak, J. A. (1981). Trigeminal chemoreception in the nasal and oral cavities. Chem. Senses 6, 295-305.

Simons, C. T., Dessirier, J. M., Carstens, M. I., O'mahony, M. and Carstens, E. (1999). Neurobiological and psychophysical mechanisms underlying the oral sensation produced by carbonated water. J. Neurosci. 19, 8134-8144.

Sneddon, L. U. (2002). Anatomical and electrophysiological analysis of the trigeminal nerve in a teleost fish, Oncorhynchus mykiss. Neurosci. Lett. 319, 167-171.

Sneddon, L. U. (2003). Trigeminal somatosensory innervation of the head of a teleost fish with particular reference to nociception. Brain Res. 972, 44-52.

Sneddon, L. U., Braithwaite, V. A. and Gentle, M. J. (2003). Do fishes have nociceptors? Evidence for the evolution of a vertebrate sensory system. Proc. $R$. Soc. Lond. B 270, 1115-1121.

Sorensen, P. W. and Caprio, J. (1998). Chemoreception. In The Physiology of Fishes, 2nd edn (ed. D. H. Evans), pp. 375-405. Boca Raton, FL: CRC Press.

Southgate, P. and Wall, T. (2001). Welfare of farmed fish at slaughter. In Pract. 23 277-284.

Summerfelt, S. T., Davidson, J., Wilson, G. and Waldrop, T. (2009). Advances in fish harvest technologies for circular tanks. Aquac. Engineer. 40, 62-71.

Swackhamer, D. L. (2005). The past, present, and future of the North American Great Lakes: what lessons do they offer? J. Environ. Monitor. 7, 540-544.

Taylor, E. W., Leite, C. A. C., Mckenzie, D. J. and Wang, T. (2010). Control of respiration in fish, amphibians and reptiles. Braz. J. Med. Biol. Res. 43, 409-424.

Toda, K., Ishii, N. and Nakamura, Y. (1997). Characteristics of mucosal nociceptors in the rat oral cavity: an in vitro study. Neurosci. Letts. 228, 95-98.

Walker, I. D. F. and Whitaker, B. R. (1996). Public aquaria. In BSAVA Manual of Ornamental Fish (ed. W. H. Wildgoose), pp. 53-62. Gloucester: British Small Animal Veterinary Association.

Wilkie, M. P. and Wood, C. M. (1994). The effects of extremely alkaline water (pH 9) on rainbow trout gill function and morphology. J. Fish Biol. 45, 87-98.

Wilkie, M. P., Simmons, H. E. and Wood, C. M. (1996). Physiological adaptations of rainbow trout to chronically elevated water $\mathrm{pH}(\mathrm{pH}=9.5)$. J. Exp. Zool. 274, 1-14.

Willis, W. D. J. (1988). Dorsal horn neurophysiology of pain. In Annals of the New York Academy of Sciences, Vol. 531, Neurological Applications of Implanted Drug Pumps Conference, New York, USA, $12-13$ June 1987 (ed. R. D. Penn), pp. 76-89. New York: The New York Academy of Sciences.

Woolf, C. J. and Ma, Q. F. (2007). Nociceptors - noxious stimulus detectors. Neuron 55, 353-364.

Yesaki, T. Y. and Iwama, G. K. (1992). Survival, acid-base regulation, ion regulation, and ammonia excretion in rainbow-trout in highly alkaline hard water. Physiol. Zool. 65, 763-787.

Yue, S. (2008). The Welfare of Farmed Fish at Slaughter. Washington, DC: The Humane Society of the United States. 